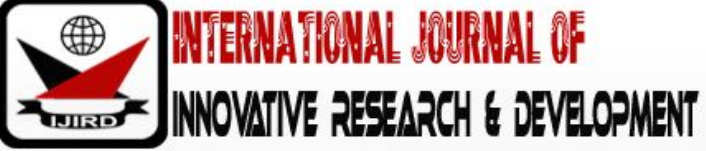

ISSN 2278 - 0211 (Online)

\section{Impact of Rainfall Erosivity on Soil Loss Rates in Biu Area, Borno State, Nigeria}

\author{
Ibrahim Madu \\ Lecturer, Department of Agricultural Education, School of Vocational Education, \\ College of Education, Waka - Biu, Nigeria \\ Abubakar M. Kundiri \\ Lecturer, Department of Soil Science, University of Maiduguri, Nigeria
}

\begin{abstract}
:
Soil loss rate from rill erosion is severe because of high rainfall erosivity in Biu Area. The aim of this present study is to assess the magnitude of soil loss from erosivity of rainfall in Biu Area. Rain gauges were installed at six locations; Kigir, Daura, Garwashina, Mirnga, Tum and Piku from April to October (2016), to measure rainfall amounts. Wishmeir and Smith 1958, 1978 models were used to calculate rainfall and runoff factor (R). The Revised Universal Soil Loss Equation 2, (2008) was to calculate erosivity and soil loss rates. The soil textures ranges from clay loam, loam, silty loam and sandy clay loam in the study area. Bulk density and percentage slope steepness ranges from $1.25-1.38 \mathrm{~g} / \mathrm{cm}^{3}$ and $10.5-12.0 \%$, respectively. Kigir, Piku, Daura, Mirnga, Garwashina and Tum sites recorded the erosivity of 726, 730, 780, 710, 715, $701 \mathrm{MJmmha}^{-1} \mathrm{hr}^{-1}$ and soil loss due to erosivity were 207.14, 248.96, 248.68, 243.02, 351.85 and $240.40 \mathrm{kgha}^{1} \mathrm{yr}^{1}$, respectively. Both erosivity and soil loss rates were significant $(\mathrm{P}<0.05)$ at locational bases. The models showed low to high prediction strength at locational and annual bases.
\end{abstract}

Keywords: Erosivity, rainfall and runoff factor, bulk density, texture, slope steepness

\section{Introduction}

Erosivity reflects the effects of both rainfall amount and rainfall intensity on erosion. Intensity is the most important rainfall property which determines the amount of erosion in a specific location. Combination of high amount of rainfall with high intensity produces high erosion risk [3]. Rainfall characteristics become more variable and stochastic in the context of climate change, which increases the uncertainties and risk of water erosion in the real world [4]. The changes in precipitation are not the same all over the world. Rainfall amount were expected to increase in the USA [5], whereas Karl [6], denoted a decreasing rainfall trend for the Mediterranean area [7]. A number of theoretical modelling and empirical analysis have suggested that the striking changes in the frequency and intensity of extreme events including floods may occur even when there are only small changes in the mean climate [8,9]. Thus soil erosion is a function of erosivity and soil erodibility (soil physical conditions, topography and vegetation / land use) [10]. Soil erosion on the sloping land has different level of difficulty in controlling erosion, the steeper the slope; the more the number of grains of soil is splashed by the impact of raindrop. This problem leads to the loss of soil slope stability due to the physical changes in the soil [11]. The eroded soil will be retained in chemical and physical properties such as loss of nutrient and organic matter, the increasing soil density and penetration resistance, the decreasing soil infiltration capacity and ability of soil to retain water. These events resulted in the decrease of land productivity and ground water recharge [12].

Biu lies on the Biu plateau at an average elevation of $768 \mathrm{~m}$, the region is semi - arid, the local Government Area (LGA) is mostly located in the Northern Guinea Savannah (NGA) agro ecological zone with small portion in the north east, the kimba area lies in the drier Sudan savannah zone [13]. Despite the high erosivity problems, there is still lack of information on the scale and magnitude of scourge in Biu. The present research is expected to provide necessary information on the extent, measures and direction for prospective users including governmental agencies and a number of policy makers on their effort to manage erosion problems in the area.

\section{Materials and Methods}

The study was conducted in Biu, North Eastern Nigeria, in 2016. Biu town is located on latitude $10^{0} 36^{1} \mathrm{~N}$ and longitude $10^{0} 13^{1} \mathrm{E}$, with an elevation of $768 \mathrm{~m}$ above sea level. Six locations Garwashina, Piku, Mirnga, Tum, Kigir, and Daura were used for the analysis in the study area. Biu town has tropical climate consisting of dry season from November to march followed by wet season from April to October. The average rainfall of the area is $917.19 \mathrm{~mm}$ [31]. The soil types vary according to the slopes of the land and locations along which they are found [32]. 


\subsection{Field Study}

The rainfall data is the 10 year - twenty four hours (24) rainfall amount and was collected using a rain gauge devise for all rainfall events during the study period. In this study the 10 year - 24 hours is term as the amount of rainfall received using a rain gauge between 9.00 am (the first day) and 9.00 am (the next day) totalling 24 hours duration having a 10 years return period. At each of the six locations, rain gauge was installed. And, rainfall data were collected from April to October, 2016. To determine the runoff factor $(\mathrm{R})[18,19]$ models were used. The models are as follows;

- $\quad \mathrm{R}=\mathrm{P} \times 0.5 \quad[14]$

- $\mathrm{E}(\mathrm{KE}<25)=9.28 \mathrm{P}-8838[15]$

Where;

- $\mathrm{EI}_{30}=0.276 \mathrm{P} \times \mathrm{I}_{30}[16]$

- $\mathrm{R}=$ run off factor

- $\mathrm{P}=$ precipitation

- $\mathrm{E}=$ erosivity

- $\mathrm{KE}=$ kinetic energy

- $\mathrm{EI}_{30}=$ energy $\mathrm{x} 30$ minutes Intensity rainfall

Then the rainfall and run off factor gotten from the above equations was use to calculate erosivity and erosivity density of the study locations. The average of the above three models was taken for the analysis. The Universal Soil Loss Equation version two of 2008 (RUSLE 2,) was used to calculate soil loss at the various sites in the study area. The model is as follows;

Where;

$$
\mathrm{a}_{\mathrm{i}}=\mathrm{ri}_{\mathrm{i}} l \mathrm{Sc}_{\mathrm{i}} \mathrm{p}_{\mathrm{i}-[2]}[2]
$$

$a_{i}=$ long term average soil loss for ith day

$\mathrm{r}_{\mathrm{i}}=$ erosivity factor

$\mathrm{ki}=$ soil erodibility factor

l = slope length factor

$\mathrm{S}=$ slope steepness factor

$\mathrm{C}_{\mathrm{i}}=$ cover and management factor

$\mathrm{p}_{\mathrm{i}}=$ support practice factor

The above model (soft ware program) was used to generate soil loss in the study area in $\mathrm{kgha}^{-1} \mathrm{yr}^{-1}$. The erodibility computed in accordance with the corresponding erodibility factor units ( $\mathrm{k}$ - values) for tropical soils describe by [17]. Slope length and steepness factor was measured using Theodellite. The length was measured in metres, and the steepness in percentage. Cover and management factor (C) was measured using [19] method. Support practice factor was estimated by [17] method.

\subsection{Determination of Soil Physical Properties}

The determination of soil physical properties was conducted in the laboratory following standard procedures. The particle size distribution was determined by Bouycous hydrometer method [20]. The bulk density $\left(\mathrm{B}_{\mathrm{d}}\right)$ was determined by cloud method [29], while the water holding capacity was measured by gravimetric water content of a given quantity of soil fully saturated with water [20].

\subsection{Soil Sampling Procedures}

Soil sampling was conducted at six locations (Kigir, Piku, Daura, Mirnga, Garwashina, and Tum), in the study area. Large plot or water shed with the size of $100 \mathrm{~m}^{2}$ [21], was used at each site. At each site one (1) large plot was selected at random and three soil samples were collected at each site for laboratory analysis. Eighteen composite samples were collected for one growing season for one year (2016), using bucket auger. Each soil sample was collected when moist in a new well - labelled Polyethene bag. The samples were air- dried ground and sieved through a $2 \mathrm{~mm}$ then prepared and analyse for some physical parameters that relates to soil erosion.

\section{Data Analysis}

The data generated were subjected to the RUSLE 2 model software program (RUSLE version 2.0) (2008), and used to generate the estimate of soil loss in the study area. Generalised linear model of statistic 10, statistical package version 10, (2013), statistically different means at $p<0.05$ were separated using SE and LSD. The soil loss trend was determined using a polynomial curve for $\mathrm{r}^{2}$ values, which showed monthly increase (positive) and decrease (negative) rates over seven months period.

\section{Results and Discursions}

\subsection{Erosivity Distribution and Runoff in the Study Area}

Table 1, shows annual rainfall, rainfall and runoff factor, and erosivity distribution of the various sites in the study area, based on 10 year - 24 hours precipitation. Daura site with high annual precipitation has high rainfall and runoff factor, high erosivity and high risk of erosion than Piku, Kigir, Garwashina, Mirnga and Tum sites. Precipitation and runoff factor and erosivity are significant at $(p<0.05)$. The average annual erosivity $(R)$ is an index of erosivity at a location (the study area). Erosivity reflects the effects of both rainfall amount and rainfall intensity. The R - values in the study area 
ranged from moderate to high. And, this showed that most of the rill and inter rill erosion were caused by moderate to high rainfall conditions within the study sites, that was why the 10 years - 24 hours precipitation was chosen for calculation of runoff [1,2]. Intensity is the most important rainfall property, which determines the amount of erosion in a specific location. Combination of high amount of rainfall with high intensity produces high erosion risk [3].

\begin{tabular}{|c|c|c|c|}
\hline Study Site & $\begin{array}{c}\text { Annual } \\
\text { Precip. (mm) }\end{array}$ & $\begin{array}{c}\text { Rainfall and Runoff } \\
\text { Factor } \mathbf{( m m} \text { ) }\end{array}$ & $\begin{array}{c}\text { Erosivity EI } \mathbf{3 0} \\
\text { (MJmmha-1hr-1) }\end{array}$ \\
\hline Kigir & 784.90 & 327.00 & 726 \\
Piku & 796.82 & 346.52 & 730 \\
Daura & 827.66 & 396.87 & 780 \\
Mirnga & 712.81 & 299.80 & 710 \\
Garwashina & 752.81 & 310.82 & 715 \\
Tum & 697.56 & 697.56 & 701 \\
SE $+\mathbf{- 0 . 0 5}$ & 20.58 & 16.01 & 11.44 \\
\hline
\end{tabular}

Table 1: Annual Precipitation, Rainfall and Runoff Factor and Erosivity of the Study Sites

Key: $\mathrm{EI}_{30}=$ Energy X 30 Minutes Intensity Rainfall

Source: (Based On Field Study, 2016)

\subsection{Topography, Texture and Bulk Density of the Study Sites}

Table 2, shows the soil texture, percentage slope, and bulk density of the study sites. Piku and Tum sites have texture of loam, and Kigir and Garwashina have clay loam, while Daura and Mirnga have silty loam and sandy clay loam, respectively. The site topography was not the same, Kigir, Daura, and Garwashina portray mountainous topography while Mirnga and Tum depicted a hilly topography and Piku showed a steep topography. The least resistant particle to erosion is silts and fine sands. Thus soils with high silts content are highly erodible. Similar observations were made by [23, 24, 25, and 3], that soils with high silt content are the most erodible and soil with restricted clay fraction, are the most susceptible to erosion. Daura, Mirnga and Tum sites with slope percentage of 10.5, and Kigir, Piku and Garwashina have slope percentages each of $12.0 \%$ and are high erodible, because the slope percentage surpasses $5 \%$. This observation concurs with that of [26], that percentage slope steepness less than $5 \%$ erosion hazard is negligible. Bulk density played a mitigating effect on soil loss (erosion) in the study area. This concurs with the report of [22, 28 and 3], that soil loss bulk density is a strong mitigatory of erosion process as obtained in this study.

\begin{tabular}{|c|c|c|c|c|}
\hline Site & Slope & \% Slope Steepness & Texture & Bulk Density (g/ $\left.\mathbf{c m}^{\mathbf{3}}\right)$ \\
\hline Kigir & mountainous & 12.0 & CL & 1.25 \\
Piku & steep & 12.0 & $\mathrm{~L}$ & 1.38 \\
Daura & mountainous & 10.5 & SL & 1.38 \\
Mirnga & hilly & 10.5 & SCL & 1.38 \\
Garwa. & Mountainous & 12.0 & CL & 1.38 \\
Tum & hilly & 10.5 & L & 1.33 \\
SE $_{(+-) \mathbf{0}, \mathbf{0 5}}$ & & $0.011 \mathrm{~ns}$ & & $0.029 \mathrm{~ns}$ \\
\hline
\end{tabular}

Table 2: Slope Percentage, Texture and Bulk Density of the Study Sites

Source: (Based on Field Data, 2016); CL = clay loam, L =loam, SL =silt loam, SCL = sandy clay loam

\subsection{Soil Loss in the Study Area}

Table 3, shows soil loss at various sites in the study area. High soil loss was recorded at Garwashina, Piku, Daura, Mirnga and Tum sites with the values of 351.85, 248.96, 248.68, 243.02, and 240.40 kgha-1yr-1, respectively. And, Kigir site depicted low value of soil loss at 207.14 kgha-1yr-1. Erosivity distribution EI30 ranged from 780 to $701 \mathrm{MJmmha}-1 \mathrm{hr}-$ 1 (Table 1). Daura recorded the highest erosivity followed by Piku, Kigir, Garwashina, Mirnga and Tum in the order of 780, 730, 726, 715, 710 and 701MJmmha-1 hr-1, respectively. Increase in rainfall erosivity will lead to increase in soil loss, and decrease in rainfall erosivity depicts a reduction in soil loss. Daura recorded high erosivity but with lower soil loss than Garwashina which recorded erosivity value lower than Daura site. These may be due to slope percentage differences at both sites (Table 2). These observations agree with that of [22 and 2], that storm erosivity is a function of both amount of rainfall and rainfall intensity and these caused soil loss in the study area.

\begin{tabular}{|c|c|}
\hline Study Site & RUSLE 2, Predicted (kgha-1 $\mathbf{y r}^{-\mathbf{1}}$ ) \\
\hline Kigir & 207.14 \\
Piku & 248.96 \\
Daura & 248.68 \\
Mirnga & 243.02 \\
Garwashina & 351.85 \\
Tum & 240.40 \\
\hline
\end{tabular}

Table 3: Soil Loss at the Study Area

Source: (Based On Field Data, 2016) 


\section{Conclusion}

The impact of rainfall erosivity was quantified using [18, 19 and 30], under same condition of Biu environment. The pattern and rate of erosivity and mass of soil loss confined to rainfall amount as the season progressed. Daura recorded the highest erosivity followed by Piku, Kigir, Garwashina, Mirnga and Tum sites in the order of 780, 730, 726, 715, 710, and 701MJmmha-1 hr-1, respectively. And, high soil loss due to rainfall erosivity was depicted at Garwashina, Piku, Daura, Mirnga, and Tum sites with the values of 351.85, 248.96, 248.68, 243.02 and 240.40 kgha-1 yr-1, respectively. Kigir site showed low value of soil loss at 207.14 kgha-1yr-1. Daura site recorded high erosivity, but with lower soil loss than Garwashina, which depicted erosivity value lower than Daura site. These may be due to slope percentage differences at both sites. The model showed low to high prediction strength at locational bases.

\section{Acknowledgement}

The authors would like to express to Nigeria's Tertiary Education Trust Fund (TETFund), through College of Education Waka - Biu, School of Vocational Education for funding the research, and much needed time and support for the field experiments. Further acknowledgement goes to the University of Maiduguri, Faculty of Agriculture and Soil Science Department for physio - chemical analysis in the laboratory.

\section{References}

i. R. P. C. Morgan (1986) Soil Erosion and Conservation, Longman Scientific and technical, published in the United States with John Wiley and Sons Inc. New York. Pp. 35

ii. USDA - ARS (2008) User Reference Guide, RUSLE 2. Washington DC.

iii. H. Blanco and L. Ratan (2008) Principle of Soil Conservation and Management, Springer Science Business Media,the Ohio State University Columbia, O. H. USA Kansas State University Hys. KS, USA.

iv. L. Wer; B.Zhang. M. Wang (2007) Effects of antecedent Soil Moisture on runoff and soil erosion in alley cropping system. Agric. Water Management 94, 54 - 62.

v. J.J. McCarthy, o. F., Canziani, N. A., Leary, D. Y. Dokken, K.SWhite (2001), Climate Change: Impacts, Adaptation and Vulnerability: Contribution of Working Group II to the Third Assessment Report of the Intergovernmental Panel on Climate Change Cambridge University Press: New York, NY, USA, Pp. 735 - 800.

vi. T. R. Karl (1998) Regional trends and Variation of temperature and precipitation. In the Regional Impacts of Climate Change: An Assessment of Vulnerability; Watson, R. T., Zyinyowera, M. C., Moss, R. H., Eds., Cambridge University Press: New York., NY, USA, Pp. $411-435$.

vii. M. C. Raws, J. A. Martinez - Casasnovas (2006).Trends in Precipitation Concentration and extremes in the Mediterranean penedez - Anoia region, N. E Spain. Clim. Chang. 74, 457 - 474.

viii. R. W. Katz, B. G. Brown (1992). Extreme events in Changing Climate: Variability is more important than average clim. Chang. 21, 289 - 302.

ix. D. Wagner (1996) Scenarios of extreme temperature events. Clim. Chang. 33, 385 - 407.

x. A. Tosiani (2011). Impact of land use change against soil erosion in sub watershed, MESAAM.Bali Province.

xi. I. A. Indiana (2011). Planting Legume Crop on Slopping Land Tempiok methods In Educational Forest Mount walat, Sukarabumi Thesis, Department of Siviculture, $\quad$ Faculty of Forestry, Boger Agricultural University.

xii. S. Arsyad (2010) Soil and Water Conservation. Bogor Agricultural University Press second Edition, second printing, Bogor.

xiii. P. S. Amaza (2007). Baseline Socio economic Survey report of Agriculture Borno Institute of Tropical Agriculture (IITA), Ibadan, Nigeria $\quad$ Pp 7.

State, Nigeria, International

xiv. E.J. Roose (1975a) Erosion ei ruissellement en Afrique de I'ruest vingr amritees de measures en petties purcelles experinmentales, Cyclo. ORSTOM Adiopodoume, Ivory Coast

xv. R. P. C. Morgan (1974) 'Estimating regional variation in Soil erosion hazard in Peninsular Malaysia, Malay Nat. J. 28, $94-106$.

xvi. $\quad$ G. R. Foster., L. J. Lane, J. D. Nowlin, J. M. Laflen, R. A. Young (1981). Estimating Erosion and Sediment Yield on field - size area', Trans.Am Soc Agric. Engr, 24, 1253 - 63.

xvii. J. S. K. Mitchell and G. D. Budnezer (1993) Fundamentals of Soil behaviours (second eds,) John Wiley. New York.

xviii. W.H. Wishmeir and D. D. Smith (1958) Rainfall energy and its relationship to soil loss Transactions of the American geophysical Union, 39, 285 - 291

xix. W. H. Wishmeir, and D. D. Smith (1978) Predicting rainfall losses; USDA - Agric. Res. Ser., Hand book 537.

xx. T. T. Trout, I. G. Garcia - Castilas and W. E. Hart. (1987). Soil Water Engineering field laboratory Manual M/S Eurasia, New Delhi India

xxi. M.J. Shipitalo. W. M. Edwards (1998) Runoff and erosion control with conservation Tillage and reduced input practices on crop watershedsSoil Tillage Res. 46, 1- 12.

xxii. A. MaCauley, and C. Jones (200) Management for soil erosion and water management model 3. Agric. Extension Communications Coordination Services, 416 Culbertson halls, Montana State University Bose man Mt. 59717; (994 - 2721).

xxiii. G. Richter and J. F. W. Neigendark (1977) Soil Erosion Process and the measurement in the German area of the the Mosalle River, earth surface, proc. 2, 261 - 78.

xxiv. R. Evans (1980) Mechanics of water erosion and their spatial and temporal controls: all empirical view point in Kirby 
xxv. J. M. Bradford, C. C. Truman and C. Huang (1992) Comparison of three measures of resistance of soil surface seals for raindrop splash. Soil technology 5, $47-56$.

xxvi. P. Stefanovit and G. Y. Varallyay (1992) State and management of soil in Hungary - In proceeding of the soil erosion and Remediation workshop, US Central and Eastern European Agro - Environmental program, Budapest, April 27 - May 1, 1992, Budapest Pp. 79 - 95.

xxvii. J. Kriszitian (1988) Talajverdelen (soil conservation) - GAFE, Merogazdasa Folskolai - Kar Gyongyos

xxviii. S. B. Wuest, J.D. William and H. T. Gollany (2006). Tillage and perennial grass effects on ponded infiltration for seven semi - arid loess soils. J soil water conservation 61,218 - 223.

xxix. Wolf. B. (2003) Diagnostic Techniques for improving crop production Haworth press USA.

xxx. The Revised Universal Soil Loss Equation (RUSLE2, 2008). Prepared for USDA - AgriculturalResearch Service, Washington DC.

xxxi. Ministry of Agriculture and Natural Resources (MANR), Biu, Borno State, Nigeria.

xxxii. B. Usman (2015). A history of Biu, Biu Emirate Study Series (BESS 003) published by Klamidas Communications Ltd. Sinti BO4 Peak plaza, Jabi Expressway, Utako Distric, Abuja Nigeria. Pp. 27- 28. 